\title{
Ekonomik Özgürlükler ve Vergi Gelirleri Arasındaki İlişki: OECD Ülkeleri Örneği ${ }^{1}$
}

\author{
ERCAN BAHTIYAR (i) ${ }^{2}$ \\ Başvuru: 31.12.2019; Düzenlenme: 31.12.2019; Kabul: 31.12.2019
}

\section{Giriş}

Geçmişten günümüze vergi gelirleri, gerek gelişmiş gerekse de gelişmekte olan ülkeler için en önemli gelir kaynă̆ı̆ır. Bir ekonomide veya toplumda meydana gelen birçok gelişme ise vergi gelirlerini etkileyen faktörler arasında yer alır. Ancak hangi faktörler, hangi kısıtlar altında vergi gelirlerini olumlu ya da olumsuz etkiler ve bununla birlikte bir ülkenin ekonomik özgürlük seviyesinin vergi gelirleri üzerindeki etkisi hangi ölçüdedir gibi sorular bu araştırmanın problemini ortaya koyar. Çalışmanın temel amacı, ekonomik özgürlüklerin vergi gelirleri üzerinde bir etkisinin olup olmadığının belirlenmesidir. $\mathrm{Bu}$ kapsamda OECD üye ülkelerinde vergi gelirlerini etkileyen faktörlerin belirlenerek ekonomik özgürlüklerin vergi gelirleri üzerindeki etkisinin ulaşılan veriler aracılığıyla değerlendirilip analiz edilmesi amaçlanmıştır.

\section{Tezin konusu}

Ekonomik olarak özgür kabul edilen ülkeler, diğer ülkelere göre yüksek büyüme

\footnotetext{
1 Maliye Ana Bilim Dalı Doktora Tezi, Uşak Üniversitesi Sosyal Bilimler Enstitüsü, 2019. Danışman: Prof. Dr. Hakkı Odabaş

2 Araş. Gör. Dr., Uşak Üniversitesi İktisadi ve İdari Bilimler Fakültesi Maliye Bölümü, Uşak, Türkiye. (email:ercan.bahtiyar@usak.edu.tr)
}

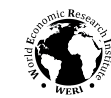

ve refah seviyesine sahip olan ülkelerdir. Mevcut büyüme ve ekonomik gelişmişlik hesaplamalarında da ekonomik özgürlükler için belirlenen şartların varlı̆̆ı oldukça önemli bir durumdur. 1990'lı yılların ortalarından bu güne standart hale getirilen ekonomik özgürlük hesaplamaları günümüzde kurumsal olarak bir gösterge halini almıştır.

Ekonomik özgürlükler ve vergi gelirleri arasındaki ilişkinin yönünün diğer faktörlerle birlikte tespit edilmesi ise araştırmanın önemini ortaya koyarken diğer taraftan ulaşılan sonuçlarla birlikte konu hakkında kapsamlı çıkarımların yapılmasını kolaylaştırmada ve ekonomik özgürlüklerin vergi gelirleri üzerindeki etkisinin göz önünde bulundurulmasını sağlayacaktır.

\section{Tezin alan içindeki yeri, önemi ve farklı yönleri}

$\mathrm{Bu}$ çalışma, literatürde yer alan ve ekonomik özgürlükler ile diğer göstergelerin ilişkisini ele alan çalı̧̧malardan, ekonomik özgürlüklerin vergi gelirlerini etkileyen bir faktör olarak ele alınarak vergi gelirleri üzerindeki etkisini belirlemek üzere gerçekleştirilmiş olmasından dolayı farklılaşmaktadır. Bu konuda yapılan araştırmalara bakıldığında vergi gelirlerini etkileyen birçok faktörün çalışma süreci içinde farklı yöntemler kullanılarak çeşitli ekonometrik analizlere tabi tutulduğu 
görülmüştür. Söz konusu çalışmalarda kullanılan veri seti; ülke grupları, değişkenler ya da zaman aralığ $\breve{g}_{1}$ açısından birbirinden farklı kısitlara sahip olduğundan ortaya çıkan sonuçlar da bu doğrultuda birbirinden farklıdır. Analizlerde yer alan verinin zaman kısıtının yanında ülke gruplarını farklı olması da genellikle önemli değişikliklerin ortaya çıkmasına neden olan etkenlerden biri olarak karşımıza çıkar. Ele alınan ülkelerin gelişmişlik seviyelerinin farklı olması durumunda dahi aynı faktörler arasındaki ilişkinin farklı yönlü sonuçları ortaya çıkardığı görülmektedir.

Tezde toplam 32 OECD ülkesinin 1996-2016 yılları arasındaki 21 yıllık verileri kullanılarak vergi gelirlerine etki eden faktörler içerisinde ekonomik özgürlüklerin etkisinin anlamlı olup olmadığı hususu incelenmiştir. Bununla birlikte mevcut etkinin hangi yönde olduğunu tespit etmek üzere vergi gelirlerini etkilediği düşünülen ve gerek teorik gerekse ampirik literatürdeki örnekleriyle desteklenen çeşitli değişkenler göz önünde bulundurulmuştur.

\section{Tezin kısa özeti}

Günümüz modern devlet anlayışı içinde var olan özgürlüklerden biri de ekonomik özgürlüklerdir. Serbest piyasa ekonomisini benimseyen bir ekonomide devlet tarafindan sunulması zorunlu temel mali ödevlerin yanında, erişilen ekonomik özgürlük seviyesinin yüksek olması için çeşitli düzenlemelerin de devlet tarafindan gerçekleştirilmesi gerekir. $\mathrm{Bu}$ düzenlemeler kapsamında diğer özgürlük alanlarıyla birlikte ekonomik özgürlüklerin de korunması ve daha iyi bir seviyeye getirilebilmesi için, devlete duyulan güvendeki artış ve bireylerin ekonomik faaliyetlerindeki serbesti, elbette ki devletin elde edeceği gelirleri daha sağlıklı ve güvenli bir şekilde toplayabilmesini sağlar. Bu gelirlerin toplanması esnasinda ise toplum ve ekonomiye etki eden birçok aktör, vergi gelirlerini de etkileyen birer faktör halini alır.
Toplam 32 OECD ülkesinin 1996-2016 yılları arasındaki verileri ele alınarak vergi gelirlerini etkilediği öngörülen faktörler ve bunlar arasında ekonomik özgürlüklere yer verilerek analiz ve değerlendirmeler gerçekleştirilmiştir. Bağımlı değişken olarak vergi gelirleri, bağımsız değişkenler olarak ise teorik ve ampirik literatürden hareketle vergi gelirlerini etkileyen seçilmiş faktörler ve ekonomik özgürlük göstergeleri kullanılmıştır. Analiz kısminda ise 32 OECD ülkesinde vergi gelirlerini etkileyen faktörler olarak ekonomik özgürlükler ve diğer seçilen faktörlerin vergi gelirleri arasındaki uzun dönemli bir ilişkinin olup olmadığ bir ilişki var ise mevcut ilişkinin yön ve derecesinin hangi seviyede olduğunun ortaya konulabilmesi için "panel veri analizi" yöntemi kullanılmıştır.

\section{Tezde işlenen konular}

Vergi gelirlerinin ekonomik gelişmenin bir parçası olması, bununla birlikte ekonomik özgürlüklerin ise ekonomik gelişmede önemli rol oynaması, bu iki kavram arasinda bir ilişkinin olabileceği anlamına gelmektedir. Buradan hareketle birinci bölümde; vergileme ile ilgili teorik gerekçeler ve vergi gelirleri derinlemesine ele alınmıştır. Devam eden kısımlarda ise vergi ile ekonomik gelişmişlik arasındaki ilişki ve vergi gelirlerini belirleyen ekonomik ve sosyal faktörler, teorik ve ampirik literatür göz önünde bulundurulmak suretiyle açıklanmaya çalışılmıştır. Bir toplumda herhangi bir ekonomik faaliyetin ya da sosyolojik olaym vergi gelirleri üzerinde de etkili olacağ 1 göz önünde bulundurularak literatürde yer alan birikim çerçevesinde belirlenen faktörler bu bölümde temellendirilmiştir.

Bir kişinin herhangi harici bir müdahale veya engelleme olmaksızın içinde hareket edebileceği alanı ifade eden özgürlük kavramının çeşitli boyutları bulunur. Çalışmanın ikinci bölümünde de özgürlük kavraminın kapsam ve boyutlarmdan hareketle, özgürlüğün hukuk, ekonomi ve 
vergileme ile ilişkisi ele alınmıştır. Ardından ekonomik özgürlük kavramı ve çeşitli teorik tartışmalar çerçevesinde, ekonomik özgürlüklerin ölçülmesi hususunda yapılan çalışmalar ve bu alanda faaliyet gösteren kurumların yaklaşımları incelenmiştir.

Üçüncü bölümde ise teorik ve ampirik literatürde vergi gelirlerine etki eden birçok değişken ile öngörülen ilişkilerinin ve yönünün ölçülmesine yönelik çalışmalar sistematik bir şekilde ele alınmıstır. Farklı değişkenler ile mevcut verilerin ve zaman aralığının müsaade ettiği ölçüde ulaşılan vergi gelirleri ve ekonomik özgürlük verileri ile diğer seçili faktörlerin göstergeleri, OECD veri bankası, Dünya Bankası açı veri sistemi ve Heritage vakfi tarafından yayınlanan yllık endekslerden elde edilmiştir. Panel veri analizi aracılı̆̆ıyla gerçekleştirilen analizlerde sirasiyla panel birim kök testleri, panel eşbütünleşme testleri, Panel FMOLS ve DOLS tahminleri ve panel nedensellik testine tabi tutulmuştur. Böylece ekonomik özgürlüklerin diğer değişkenlerle birlikte vergi gelirleri üzerindeki etkisinin ampirik sonuçlarına ulaşılmıştır.

Analiz kapsamında ele alman 32 OECD ülkesinde vergi gelirleri ile ekonomik özgürlükler ve diğer değişkenler arasındaki uzun dönem ilişkisi panel eşbütünleşme testleri ile sınanmıştır. Aralarında uzun dönem ilişkisi tespit edilen değişkenler için uzun dönem katsayı tahmini ise FMOLS ve DOLS yöntemleri ile gerçekleştirilmiştir. Değişkenler arasındaki nedensellik ilişkisi ise panel nedensellik testi aracılığıyla analiz edilmiştir. Analizde bağımsız değişken olarak, vergi gelirleri üzerinde etkisi olduğu ampirik ve teorik literatürde genel kabul gören, kişi başına düşen GSYH, işsizlik, imalat, sanayi ve ihracat gibi faktörler kullanılmıştır. Modele dahil edilen bu değişkenler ile birlikte vergi gelirlerine etki eden diğer bir faktör olarak ekonomik özgürlük seviyesinin ise sinırlı ampirik literatürle benzerlik gösterecek şekilde istatistiksel olarak anlamlı ve pozitif bir etkisinin olduğu sonucuna ulaşılmıştır.

\section{Tezin hedef kitlesi}

Ele alınan konular itibariyle hem maliye hem de iktisat alanında çalı̧̧an teorisyenler ve araştırmacılar hedeflenmektedir. Özellikle tezin birinci ve ikinci bölümleri, vergi gelirlerine etki eden faktörlerin yanında ekonomik özgürlükler üzerine incelemeler yapan araştırmacılara yönelik kapsamlı ve derinlemesine bilgiler içermektedir. 